\title{
磁気立体回路素子の材質と磁束制御特性との関係
}

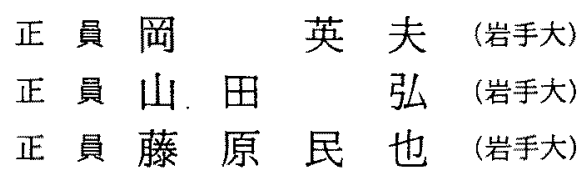

\section{Relation between Material and Flux Control Characteristic of Ferrite Orthogonal Core}

Hideo Oka, Member, Hiroshi Yamada, Member, Tamiya Fujiwara, Member (Iwate University)

In this paper, the relationship between material and the flux control characteristic of a ferrite orthogonal core (FOC) as a measurement and control element, is presented.

Five types of materials are examined to know the difference between their flux control characteristics. Results show that the material which has higher amount of saturation flux density can make its flux control amount bigger.

It is clear that the higher rectangular factor material has the larger amount of flux control. Furthermore, the material which has low loss but high saturation flux density shows good linear flux control characteristic. FOC which has good rectangular factor and high flux sensitibity is useful for measurement control element, especially for the on-off activity.

キーワード：磁気立体回路素子，直交磁心，磁束制御，フェライト

\section{1.まえがき}

フェライトで作製した直交磁心(1) ゙ある磁気立 体回路菜子(5) (7) は，直交磁界て磁束制御することに より複数の磁路が生じ, 著しい磁束の疎密を磁気立体 回路素子内に生じることになる。しかし，このために 磁気立体回路素子の各部の磁束, 透磁率柱よびインダ クタンスなどの值を変えることができるほか, 脚部間 の磁束差を利用できるなどの特徴を有するため，磁気 立体回路素子を計測・制御素子として利用すると, 磁 束を媒体として信号検出と信号処理双方の機能を有す る計測器を簡単な回路構成で製作することが可能とな $3^{(5) \sim(7)}$ 。

そこで, 著者らは上述の特徵を生かした電流セン $\#^{(5)}$ および直線, 傾斜, 回転などの変位センササ(8)(9) 考案・試作し, 計測・制御素子としての基礎特性およ U動作機櫣 ${ }^{(10)}$ 形状効果 $^{(6)}$ を明らかにしてきた。

電学諭D, 112 巻 11 号, 平成 4 年
しかし，磁気立体回路素子の材質特性と磁束制御特 性の制御性能についての報告はほとんどなされていな い。

そこで, 本研究では磁気立体回路素子の材質特性に よる磁束制御特性の差異を明らかにすべく，ここでは フェライトが数多くの種類を有する特色ある材質であ り材質特性を議論するには最適な林料と考えられる。 また，このフェライトで論じたことは今後他の材料に も大いに有効と思われる。よって，5種類のフェライ 卜を例にあげ，磁気立体回路素子の磁性材料の材質に よる磁束制御特性の差異と計測・制御素子として用い る観点より，磁束制御性能について明らかにする。

更に，これらの結果を踏まえて，電流を入力信号と する磁気立体回路菜子の磁束制御法について, 主とし て線形な制御特性 ${ }^{(5)} と し て$ 利用する場合と，非線形 な制御特性 (14) として利用する場合とに分類し，その 利用方法について㛟討を加えている。 


\section{2. 試料および測定回路}

図 1 は磁気立体回路素子の形状と寸法を示してい る。この試料は最もスタンダードな磁気立体回路索子 の形状の一例である。次にここで用いる各試料の材 質名を示す。また各試料の名称を右記の略号で述べる ことにする。

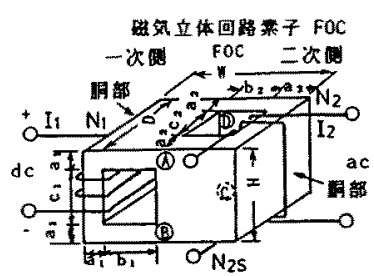

$$
\begin{aligned}
& \text { (A) (B) (C) (D) : } \\
& \text { H: 10, } 0: 10, \quad \text { : }: 16 \quad(\mathrm{~mm}) \\
& a_{1}, a_{2}: 2, b_{1}, b_{2}: 6, c_{1}, c_{2}: 6
\end{aligned}
$$

図 1 磁気立体回路素子の形状寸法

Fig. 1. Shape and size of FOC.

衰 1 各フェライト材制の材質標準特性

Table 1. Standard material characteristic of each Ferrite.

\begin{tabular}{l|c|c|c|c|c}
\hline & $\begin{array}{c}B_{s} \\
(\mathrm{mT})\end{array}$ & $\begin{array}{c}H_{c} \\
(\mathrm{~A} / \mathrm{m})\end{array}$ & $\Gamma$ & $\begin{array}{c}T_{c} \\
\left({ }^{\circ} \mathrm{C}\right)\end{array}$ & $\mu_{\text {max }}$ \\
\hline $\mathrm{Mn} \cdot \operatorname{Zn}(L)$ & 500 & 20 & 0.16 & 250 & 2,200 \\
\hline $\mathrm{Mn} \cdot \mathrm{Zn}(B)$ & 490 & 9.3 & 0.20 & 180 & 4,600 \\
\hline $\mathrm{Mn} \cdot \mathrm{Cu}(T)$ & 300 & 11 & 0.53 & 50 & 9,000 \\
\hline $\mathrm{Ni} \cdot \mathrm{Zn}(L)$ & 250 & 16 & 0.24 & 100 & 3,600 \\
\hline $\mathrm{Mn} \cdot \mathrm{Mg}(R)$ & 300 & 6.4 & 0.93 & 160 & 7,500 \\
\hline
\end{tabular}

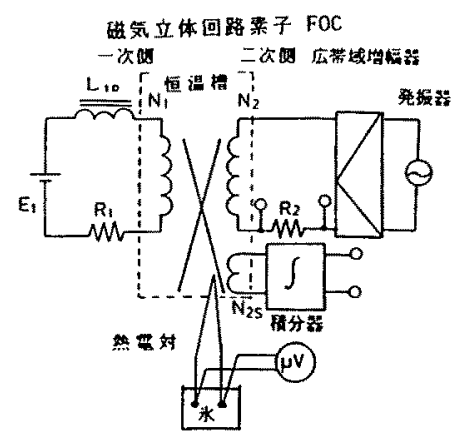

$L_{1 D}=500 \mathrm{mH}, N_{1}=20, N_{2}=12, N_{2 s}=1$ $R_{1}=7 \Omega, R_{2}=1.01 \Omega$

図 2 交流磁化特性㧍よひ磁束制御特性の 測定回路

Fig. 2. Measuring circuit for $A C$ magnetic characteristic and flux control characteristic. （i）比較的飽和磁束密度の高い $\mathrm{Mn}-\mathrm{Zn}$ 系フェラ イト: $\mathrm{Mn}-\operatorname{Zn}(B)$

(ii) 低攅失の $\mathrm{Mn}-\mathrm{Zn}$ 系フェライト: $\mathrm{Nn}-\mathrm{Zn}(L)$

(iii) インダク夕用の $\mathrm{Ni}-\mathrm{Zn}$ 系フェライト：Ni$\mathrm{Zn}(L)$

(iv) 角形七ステリシス特性を有する $\mathrm{Mn}-\mathrm{Mg}$ 系 フェライト : $\mathrm{Mn}-\mathrm{Mg}(R)$

(v) $\mathrm{Mn}-\mathrm{Cu}$ 系感温フェライト（キュリ一温度 $\left.50^{\circ} \mathrm{C}\right): \mathrm{Mn}-\mathrm{Cu}(T)$

表 1 は上記の試料の主な材質標準特性(11)てある。 同図に示すように，各材料の飽和磁束密度 $B_{s}$ ，保磁 力 $H_{c}$, 角形比 $\Gamma$, キュリ一温度 $T_{c}$, および最大透 磁率 $\mu_{\max }$ 示す。

図 2 は磁気立体回路素子の交流磁化特性および磁柬 制衔特性の測定回路である。これらの測定はJIS 規 格(12) 参考に行った。磁気立体回路素子を恒温慒に 入れ，磁気立体回路素子の一次側励磁巻線 $N_{1}$ に声流 電流を加え拘束磁化条件の下で励磁する。更に，二次 側励磁巻線 $N_{2}$ に発振器出力を広带域增幅器で堌幅し た電圧を印加し，磁束正弦波条件で励磁を行う。ま た，磁気立体回路菜子の胴部に探りコイル $N_{2 s}$ を施 し，各磁束を測定する。表面温度は，磁気立体回路素 子の脚部に熱電対を接触ざせることによりマイクロボ ルトメータで求められる。測定手㵋は初めに一次側起 磁力 $F_{1}$ の值を設定して交流磁化特性 $\left(\phi_{2}-F_{2}\right.$ 特性) を 測定する。次に，二次側起磁力 $F_{2}$ を指定の值に設定 し，磁束制御特性 ( $\phi_{2}-F_{1}$ 特性)を測定した。

\section{3. 測定結果}

〈3.1〉交流磁化特性およひ磁束制御特性 図 3 估二次側起磁力 $F_{2}$ を $20 \mathrm{~A}$ ，励磁周波数 $f_{2}$ 加 $1 \mathrm{kHz}$

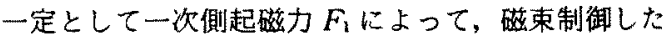
埸合の各試料の二次側 $\phi_{2}-F_{2}$ 特性の夷測例である。 これらを見ると，いずれの試料も一次側起磁力 $F_{1} に$ よって二次側の交流磁化特性が磁束制御されているこ とがわがっだ。

図 4 (a)一(e)はそれぞれ $\mathrm{Mn}-\mathrm{Zn}(L), \mathrm{Mn}-\mathrm{Zn}$ (B), $\mathrm{Mn}-\mathrm{Cu}(T), \mathrm{Ni}-\mathrm{Zn}(L), \mathrm{Mn}-\mathrm{Mg}(R)$ て作成 した磁気立体回路素子の一次側起磁力 $F_{1}$ に上り磁束 制御を行った場合の交流磁化特性である。

図 5 は交流磁化特性の励磁振幅の説明図である。二 次側起磁力 $F_{2}$ を小振幅，中振幅，大振幅と定め，磁 束レヘル設定による各振幅領域における二次側磁束 $\phi_{2}$ と二次側起磁力 $F_{2}$ の傾き $\Delta \phi_{2} / \Delta F_{2}$ に着目する。 この三つの振幅レベルを図 4 の結果に適応してみると 磁束制推することにより小振幅領域が增し，中振幅領 
域が次第に右側に移動することがほとんどの試料で認 められた。

図 6 は図 5 に示した中振幅領域の傾き $\Delta \phi_{2} / \Delta F_{2}$ の 最大值を図 4 の結果より求めたものである。同図に示 すように, 磁束制御によって傾き $\Delta \phi_{2} / \Delta F_{2}$ の最大値 は隇少する傾向を示すことがわかる。この原因は, 磁 気立体回路素子の片側励磁の場合よりも両側励磁の場

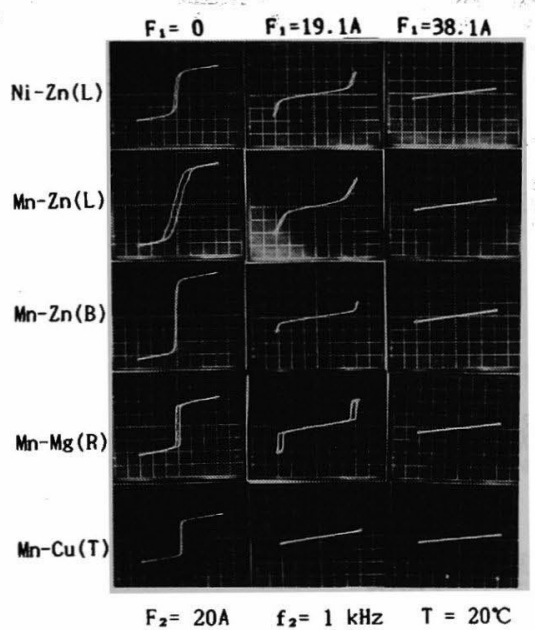

図 3 磁束制御時の各試料の二次側 $\phi_{2}-F_{2}$ 特性 Fig. 3. Secondary $\phi_{2}-F_{2}$ characteristic under flux control.

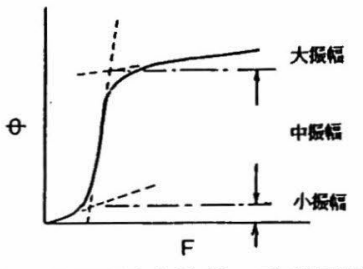

図 5 交流磁性化特性の励磁振幅と 傾きの説明図

Fig. 5. Explanatory figure of exciting amplitude and inclination in AC magnetizing characteristic.

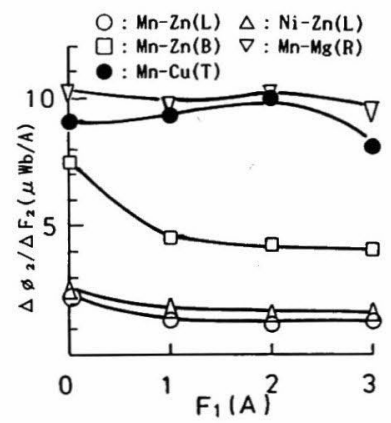

図 6 各フェライトの中振幅領域の

傾き $\Delta \phi_{2} / F_{2}$

Fig. 6. Inclination of each ferrite $\Delta \phi_{2} / \Delta F_{2}$.

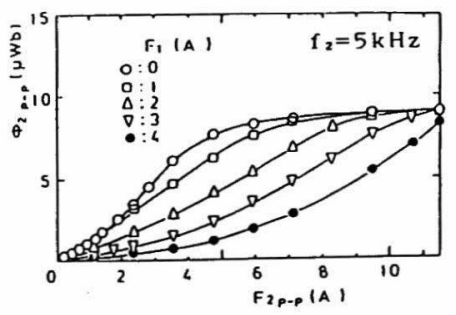

(a) $\mathrm{Mn}-\operatorname{Zn}(L)$

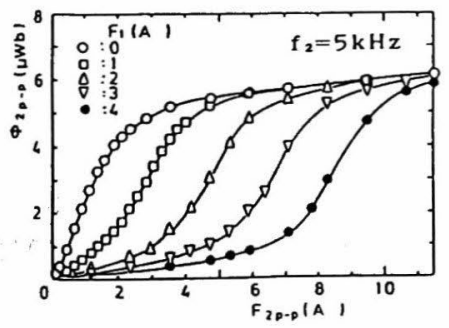

(d) $\mathrm{Ni}-\mathrm{Zn}(L)$

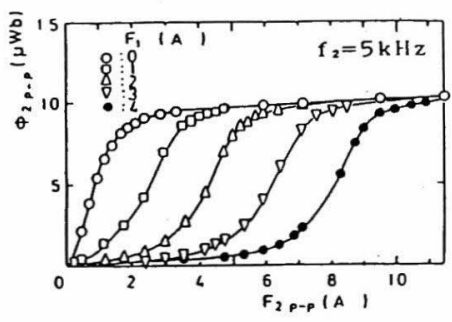

(b) $\operatorname{Mn}-\operatorname{Zn}(B)$

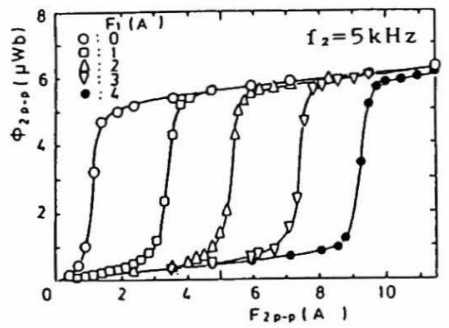

(e) $\mathrm{Mn}-\mathrm{Mg}(R)$

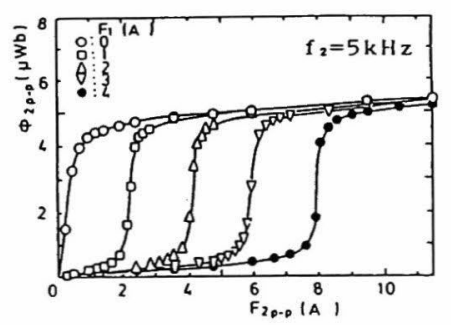

(e) $\mathrm{Mn}-\mathrm{Cu}(T)$

図 4 一次側起磁力により磁束制御した場合の交流磁化特性

Fig. 4. AC magnetic characteristic when flux is controlled by the primary magnetomotive force. 


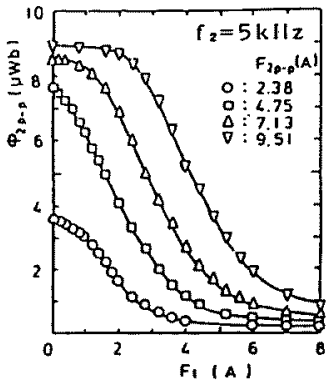

(a) $\operatorname{Mn}-\operatorname{Zn}(L)$

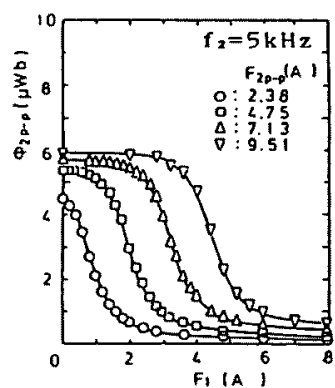

(d) $\mathrm{Ni}-\mathrm{Zn}(L)$

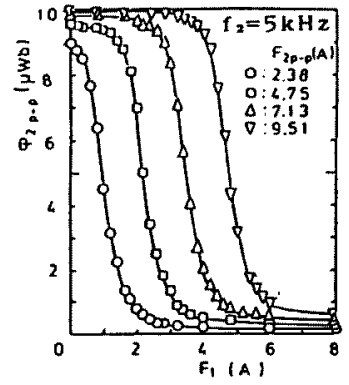

(b) $\mathrm{Mn}-\mathrm{Zn}(B)$

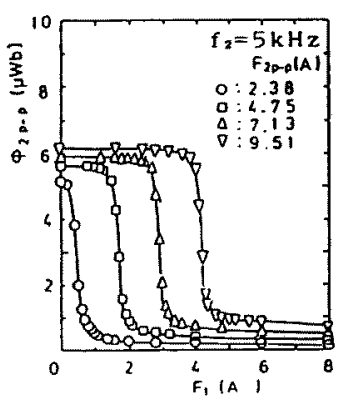

(e) $\mathrm{Mn}-\mathrm{Mg}(R)$

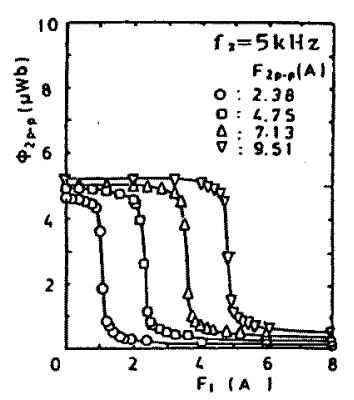

(c) $\mathrm{Mn}-\mathrm{Cu}(T)$

図 7 磁気立体回路素子の磁束制御特性

Fig. 7. Flux control characteristic of FOC.

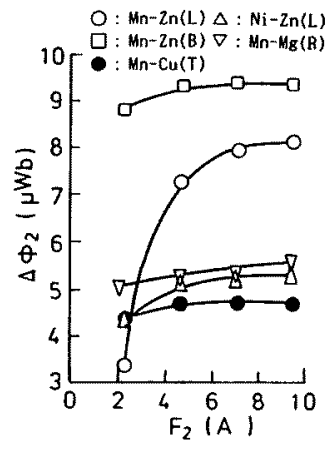

(a) 制御量 $\Delta \phi_{2}$

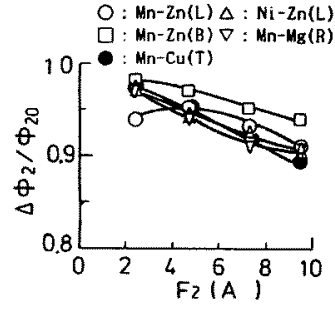

（b）磁束制御 $\Delta \phi_{2} / \phi_{20}$

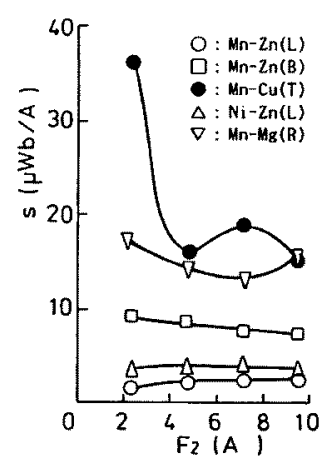

(c) 磁束制御感度 $s$

図 8 磁束制御特性の基本性能

Fig. 8. Basic performance of flux control characteristic.

合が磁路長が長いことに起因すると考えられる。ただ し, 角形比 $\Gamma$ の良好な $\mathrm{Mn}-\mathrm{Mg}(R)$ と $\mathrm{Mn}-\mathrm{Cu}(T)$ は ほとんど変化割合が少ないことがわかる。

更に, 図 7 (a) （e）は磁気立体回路素子の磁束制 御特性を示している。同図より, 最大透磁率 $\mu_{\max }$ 预 よび角形比 $\Gamma$ の高い值を有する材質は, 一次側起磁 力 $F_{1}$ により二次側磁束 $\phi_{2}$ が急激に変化する領域を 有する磁束制御特性を示すことが認められた。

図 8 (a) 〜 (c) は, それぞれの試料について磁束制 御の性能評価係数 ${ }^{(10)(13)}$ である磁束制御量 $\Delta \phi_{2}$, 磁束
制御率 $\Delta \phi_{2} / \phi_{20}$, および磁束制御感度 $s$ の測定結果を 示している $\left(\phi_{20}\right.$ : 一次側起磁力 $F_{1}$ が零の場合の二次 側磁束 $\phi_{2}$ を呼灾)。

同図より，磁束制御量 $\Delta \phi_{2}$ は材質特性である飽和 磁束密度 $B_{s}$ に対応するこもが考えられる。更に(b) 図より，実験で用いた材質の磁気立体回路素子はすべ て磁束制御率 $\Delta \phi_{2} / \phi_{20}$ が特性の 0.9 以上の値を示して いることがわかる。この結果より, 磁東制御率 $\Delta \phi_{2} / \phi_{20}$ は材質にはほとんど影響されないことが認められた。 また, (c)図より磁束制御感度 $s$ は材質特性の角形比 
によるものと思われる。

図 9 は磁束制御特性の制御領域の㜔明図である。図 示のように，磁気立体回路素子の磁束制御特性はI, II, IIの 3 領域に分けることができる。

图 10(a)，(b)は非線形特性あるいは線形特性と して利用する場合の磁束制御特性に分類し，その利用 法について検討する。（a）図はI 領域とIII領域部分を 利用する特性で，二次側磁束 $\phi_{2}$ と一次側起磁力 $F_{1}$

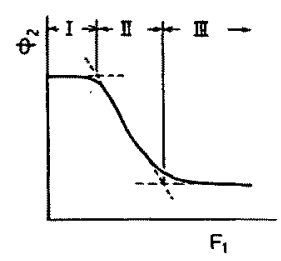

图 9 磁束制御特性の制御領域

Fig. 9. Control range of flux control characteristic.

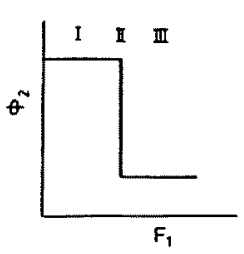

（a）１領域とIII領域を利用する場合

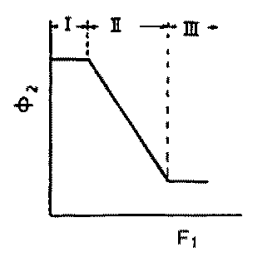

（b）II領域を利用する場合
図 10 非線形および線形特性として利用する 場合の磁束制御特性

Fig. 10. Corresponding figure of II region in flux control characteristic.
の関係が非線形な領域を主に利用する特性である。 (b)図は主にII領域部分を利用する特性である。以上, 2 通りの磁束制御特性の利用方法に分類できるものと 考えられる。（a）図に示す非線形な特性としてはオン オフ動作 ${ }^{(14)}$ を行う計測・制御素子として適していると 考えられる。この場合, 磁束制御率 $\Delta \phi_{2} / \phi_{20}$, 感度 $s$, が高い值を示すことが望ましいと考えられる。これら の結果を踏まえ, 図 7, 図 80 結果より $\mathrm{Mn}-\mathrm{Mg}(R)$, $\mathrm{Mn}-\mathrm{Cu}(T)$ などの角形比の高い值を有する材質の磁 気立体回路素子が対応するものと考えられる。

(b)図に示す $\phi_{2}$ と $F_{1}$ の関係が線形な特性として II領域を応用することが望ましいとする計測・制御素 子は $\phi_{2}$ と $F_{1}$ との関係が線形性に優れ，磁束制御量 $\Delta \phi_{2}$ ，磁束制御率 $\Delta \phi_{2} / \phi_{20}$ が高い值を示すことが望ま しいものと考えられる。これらの考えに基づき図 7， 図 80 結果より $\mathrm{Mn}-\mathrm{Zn}(L), \mathrm{Mn}-\mathrm{Zn}(B), \mathrm{Ni}-\mathrm{Zn}(L)$ などの飽和磁束密度の高い值を示す材料が対応するこ とがかかる。

〈3・2〉周波数特性ここでは，各材筫の特性の 違いによる二次側起磁力 $F_{2}$ を一定とした二次側磁束 $\phi_{2}$ の磁束制御特性を測定し，磁束制御による二次側 磁束の周波数特性への影響について明らかにする。

図 11( a ) (d) は各 $\mathrm{Mn}-\mathrm{Zn}(B), \mathrm{Mn}-\mathrm{Cu}(T)$, $\mathrm{Ni}-\mathrm{Zn}(L), \mathrm{Mn}-\mathrm{Mg}(R)$ の磁束制御時の二次側磁束 $\phi_{2 p-p}$ の周波数特性である。これらの結果は材質本来 の特性の交流初透磁率 $\mu_{i \mathrm{AC}}$ よりも低い值であり，ま た磁束制御によりほとんどの試料では磁束值が減少す ることを示していることが了解される。

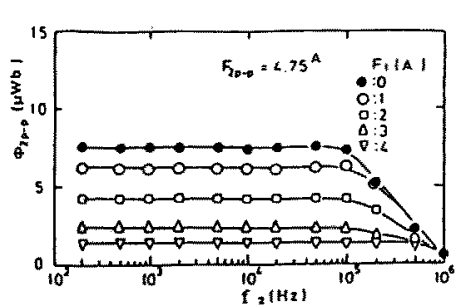

(a) $\operatorname{Mn}-\mathrm{Zn}(L)$

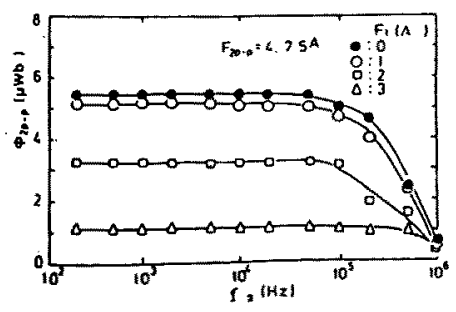

(d) $\mathrm{Ni}-\mathrm{Zn}(\mathrm{L})$

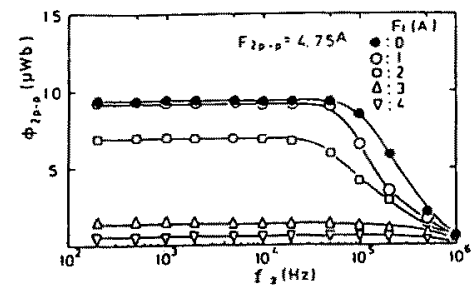

(b) $\mathrm{Mn}-\mathrm{Z}(B)$

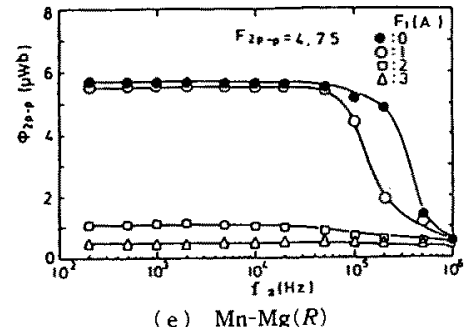

図 11 二次側磁束の周波数特性

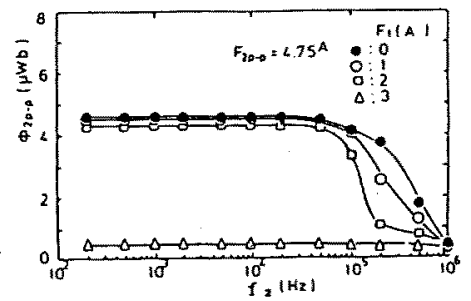

(c) $\mathrm{Mn}-\mathrm{Cu}(T)$

Fig. 11. Frequency characteristic of the secondary flux. 


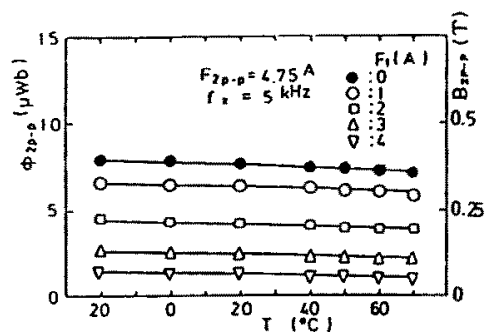

(a) $\operatorname{Mn}-\operatorname{Zn}(L)$

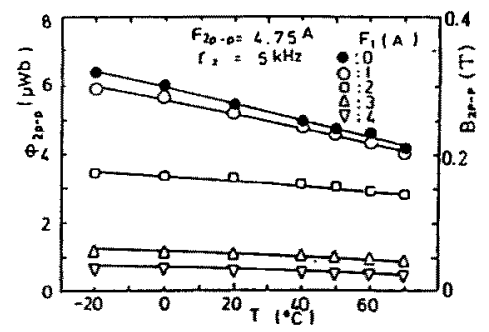

(d) $\mathrm{Ni}-\mathrm{Zn}(L)$

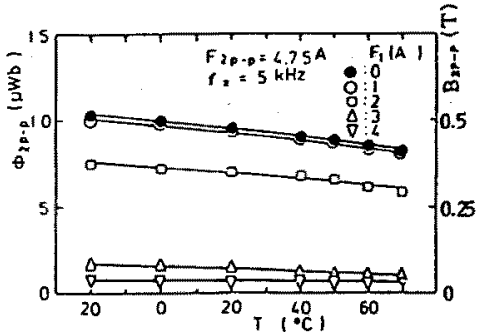

(b) $\operatorname{Mn}-\operatorname{Zn}(B)$

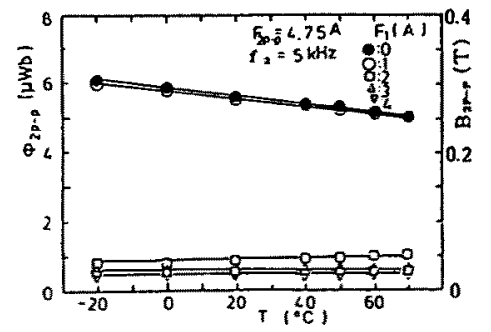

(e) $\mathrm{Mn}-\mathrm{Mg}(R)$

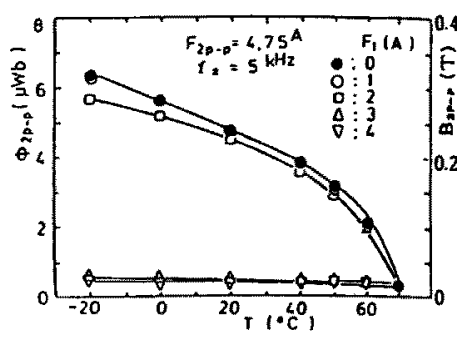

(c) $\mathrm{Mn}-\mathrm{Cu}(T)$

図 12 二次側磁束の温度特性

Fig. 12. Temperature characteristic of the secondary flux.

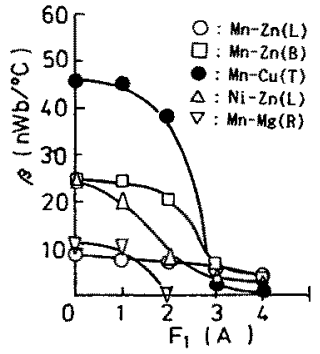

図 13 磁気立体回路䋕子の温度係数

Fig. 13. Temperature coefficient of FOC.

〈3.3〉温度特性許测に用いるための酳気立体 回路素子では温度変化に対する磁橆特性の安定性が重 要な要素となる。そこで，ここでは磁気立体回路素子 の二次側磁束の温度特性について明らかにする。

図 12 に磁束制御を行った場合の二次側磁束の温度 特性を示す。(a) (d)应はそれぞれ $\operatorname{Mn}-\operatorname{Zn}(B)$ ， $\mathrm{Mn}-\mathrm{Cu}(T), \mathrm{Ni}-\mathrm{Zn}(L), \operatorname{Mn}-\mathrm{Mg}(R) の$ 二次側磁柬 の温度特性である。以上の結果より, 温度が $1^{\circ} \mathrm{C}$ 变化 した場合の二次側の二次側磁束の変化量を温度係数 $\Delta \beta / \Delta T^{(13)}$ として求めると，一次側起磁力 $F_{1}$ を印加 した場合の温度係数は図 13 のうに求められる。同 図より，感温フェライトである $\mathrm{Mn}-\mathrm{Cu}(T) は$ 温度に 対し影著な磁束の変化を示すことが認められた。

また，各試料とも磁束制御により温度係数は小さく
なることが認められた。一方，本実験に用いた試料中 最もキュリ一温度が高い值を示している $\mathrm{Mn}-\mathrm{Zn}(L)$ は，磁束制御による温度係数への影響が最も少ない值 を示すことが丁解される。

〈3・4〉磁束波形のUすみ率特性磁気素子を铇 和領域まで励磁すると，一般に非線形特性のため磁束 波形あるいは起磁力波形のどちらか，もしくは双方に 波形ひずみが生じる。従って，励磁回路の条件は起磁 力か磁束のどちらか一方の波形が正弦波となるように 設定する必要がある。本研究の場合はフェライトの特 徵を生かして，高周波領域での使用が考光られるこ と，また，滦加電子デバイスとの結合も考慮し，磁 束正弦波条件に設定することにした。またこの条件 がどの程度满足されているか，あるいは制御起磁力を 加えることによる二次側磁束波形の変化がどのように なるかなどを知るために，その磁束波形のひずみ 率(15) をスペクトラムアナライザを用いて测定するこ とにした。

図 14(a)は $\mathrm{Mn}-\mathrm{Zn}(L)$ 二次側磁束波形のひず 率の測定結果である。また（b)〜(e)図はそれてれ $\mathrm{Mn}-\mathrm{Zn}(B), \mathrm{Mn}-\mathrm{Cu}(T), \mathrm{Ni}-\mathrm{Zn}(L), \mathrm{Mn}-\mathrm{Mg}(R)$ の磁気立体回路素子の場合のひする率特性を示してい る。これらの結果より，一次側起磁力 $F_{1}$ を加える と，いつたんひずみ率は減少するが，F増大させ ていくとひずみ率が上昇し，亟大值をとった後に再び

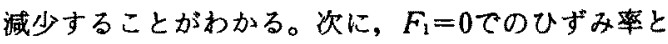




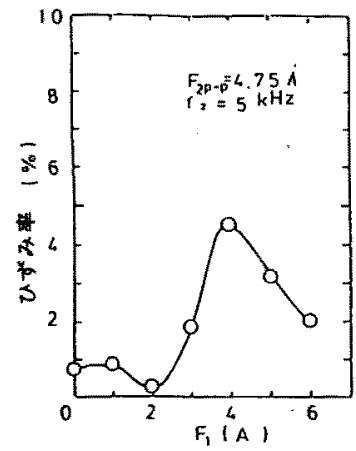

(a) $\operatorname{Mn}-\mathrm{Zn}(L)$

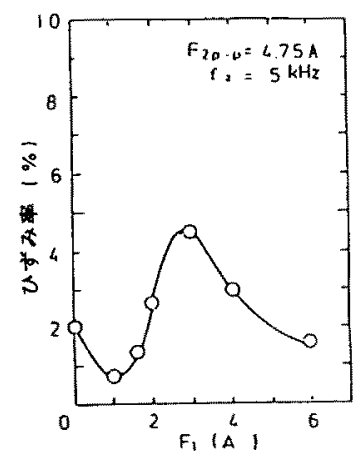

(d) $\mathrm{Ni}-\mathrm{Zn}(L)$

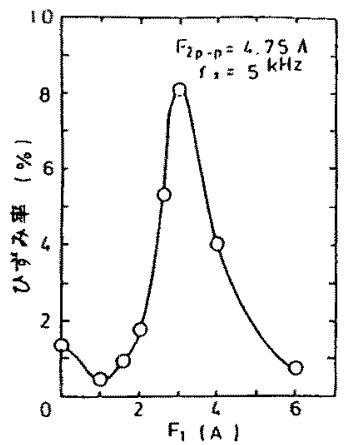

(b) $\mathrm{Mn}-\mathrm{Zn}(B)$

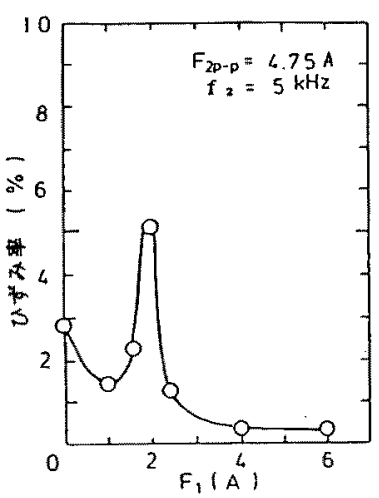

(e) $\mathrm{Mn}-\mathrm{Mg}(R)$

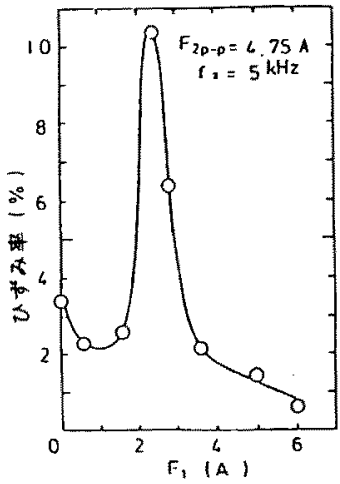

(c) $\mathrm{Mn}-\mathrm{Cu}(T)$

図 14 二次側镃束波形のひずみ率

Fig. 14. Distortion factor of the secondary flux wave.

表 2 一次側起磁力 $F_{1}=0$ におけるひずみ率と Uずみ率の最大值

Table 2. Destortion factor and its maximum value of the secondary flux wave when the primary magnetomotive force is $F_{1}=0$.

\begin{tabular}{|c|c|c|}
\hline & 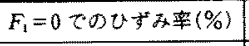 & さず为邫の最大值（\%) \\
\hline $\operatorname{Mn} \cdot \operatorname{Zn}(L)$ & 0.7 & 4.5 \\
\hline $\operatorname{Mn} \cdot \operatorname{Zn}(B)$ & 1.33 & 8.12 \\
\hline $\mathrm{Mn}-\mathrm{Cu}(T)$ & 3.35 & 10.4 \\
\hline $\mathrm{Ni}-\mathrm{Zn}(L)$ & 2.05 & 4.65 \\
\hline $\mathrm{Mn}-\mathrm{Mg}(R)$ & 2.84 & 5.15 \\
\hline
\end{tabular}

ひずみ率の最大值を材料ごとに書き表すと表 2 のよう になる。このように磁束制御すると二次側磁束波形の ひずみ率が大きくなることを示している。また，材質 特性の最大透磁率 $\mu_{\max }$ の値が高い試料はひずみ率が 比較的高い值を示すことがかかった。

以上，各材質で作成された磁気立体回路素子に対す る磁束制御特性と材質特性との関連性について簡単な 評価を行った結果, 制御時の交流磁化特性の中振幅領
域の傾き $\Delta \phi_{2} / \Delta F_{2}$ の最大值はほ涩角形比に対応する ことが認められた。また，磁束制御特性については, 磁束制御量 $\Delta \phi_{2}$, 磁束制御率 $\Delta \phi_{2} / \phi_{20}$, 磁束制御感度

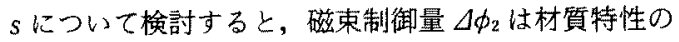
飽和磁束密度に対応し, 磁束制御感度 $s$ は角形比に関 係する。しかし，磁束制御率については，材質による 影響がほとんど見られないことが了解された。

\section{4.むすび}

以上，磁気立体回路素子の材質については比較的飽 和磁束密度の高い $\mathrm{Mn}-\mathrm{Zn}$ 系フェライト，低損失の $\mathrm{Mn}-\mathrm{Zn}$ 系フェライト，低損失インダクタンス用 $\mathrm{Ni}-$ $\mathrm{Zn}$ 系フェライト，角形比に優れた $\mathrm{Mn}-\mathrm{Mg}$ 系フェラ イト系 $\mathrm{Mn}-\mathrm{Cu}$ 系感温フェライトなどの各種フェライ 卜を例にして，磁気立体回路素子を構成し，それぞれ の磁東制御特性を中心に次のことを明放にした。

（1）飽和磁束密度が高い材質ほど磁束制御量を大 きくできる。

（2）磁束制御率には材䨘特性の違いがほとんど現 
れない。

（3）磁束制御感度は角形比に大きく影響されるた め, 角形比の高い $\mathrm{Mn}-\mathrm{Mg}$ 系フェライトおよび $\mathrm{Mn}$ $\mathrm{Cu}$ 系感温フェライトで作製した磁気立体回路素子が 高い值を示す。

（4）低損失の $\mathrm{Mn}-\mathrm{Zn}$ 系フェライトで作られた磁 気立体回路素子の磁束制御特性の主な利用法は，線形 な制御特性として用いることが望ましいと思われる。

（5） Mn-Mg 系フェライトで製作した磁気立体回 路素子は角形比が優れているため, 磁気立体回路素子 の磁束制御感度は高いものとなる。従って,この磁気 立体回路素子の二次側の最大值と最小値の間でオンオ フ動作を行う計測・制御素子へ(14) として用いることが 適している。

（6）キュリー温度の高い材質で作製した磁気立体 回路素子は，磁束制御による温度係教への影響が最も 少ないことが明らかになった。

（7）磁束波形のひずみ率は最大透磁率の高い材質 で作製した磁気立体回路素子が比較的高い值を示すこ とがわかった。

今後, 磁性材料の材質特性より磁気立体回路素子の 交流磁化特性および磁束制御特性を簡単に導き出すこ とのできる磁気立体回路素子の最適設計法を確立する と共に, アモルファス材などメタル系の薄帯を積層し 作製した磁気立体回路素子(16) および複合磁気立体回 路素子(17) の材質特性を十分に生かせる構成方法, 更 には最適応用についても明らかにしていきたい。

最後に, 日ごろ指導を賜る東北大学名誉教授（八戸 工大副学長）村上孝一先生に深謝いたします。

(平成 3 年 10 月 4 日受付, 同 4 年 3 月 4 日再受付)

$$
\text { 文献 }
$$

(1) S. D. Wanlass, et al.: "The Paraformer; A new passive power conversion device", Eng. Sci., p. 9 (1968)

(2) W. Z. Fam \& R. P. Verma: "Steady-State analysis of parametric frequency changers", IEEE Trans. Magnetics. MAG-13, No. 4, 1070 (1977)

(3) Z. H. Meiksin: "Comparison of orthogonal and parallelflux variable inductors", IEEE Trans. Industr Applic., IA-10, No. 3, 417 (1974)

(4) O. Ichinokura \& K. Murakami: "Graphical circuit analy. sis of Two C-core type parametric power converter". IEEE Trans. Magnetics, MAG-14, No. 5, 1002 (1978)

(5) H. Oka \& J. Iwata: "A New Frequency Modulator using Ferrite Orthogonal Core", IEEE Trans. Magetics, MAG17, No. 1, 1174 (1981)

（6）岡：「磁束成分による磁気立体回路素子の形状効果と磁束制 御特性の性能評価」, 電学論 D, 112, 387 (平 4-4)

（7）岡：「直交磁路を利用した磁気回路素子の歩みと現状」、電 気学会計測・マグネティックス合同研资, IM-87-13; MAG87-38, 19 (昭 52)
(8) H. Oka: "New FM Tachotelemeter using Ferrite Orthogonal Core", IEE Proc. Pant A, 131, No. 8, 601 (1984)

（9）岡・岩田：「磁性流体に上了磁気立体回路素子の磁束制御特 性」, 信学論 (C), J69-C, 206 (昭 61-2)

(10) H. Oka \& P. P. Biringer: "Control Characteristic Analy sis of a Ferrite Orthogonal Core", IEEE Trans. Magetics, 25, No. 5, 2888 (1990)

(11) Tokin: Ferrite Pot Cores Data Book (1977) Tohoku Metal Industries, Ltd.

（12）日本工業規格：「フェライト磁心の材質性能試呀方法」ＪIS C 2561-1981

(13）岡：「磁気立体回路素子の磁束制御と計測への応用に関する 研究」, 東北大学工学博士学位論文 工第 984 号 (昭 63)

（14）岡・岩田：「三值パルス出力型磁気立体回路素子の基本動 作」, 信学論 C, J70-C, 939 (昭 62)

（15）日本工業規格：「電子湖定器用語」, JIS C 1002-1975

（16）岡・岩田：「磁気立体回路素子の材質について」, 第 8 回日本 応用磁気学会学術講演概要集, $15 \mathrm{pD}-2$ (昭 59)

（17）岡・岩田：「磁気立体回路素子の構成方法江関する基礎的检 討」, 電気学会マグネティックス研資, MAG-83-94, 35 (昭 58)

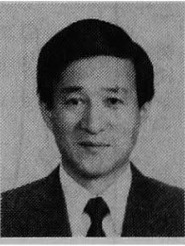

岡英 夫（正員）

昭和 48 年岩手大学大学院工学研究科 修士課程修了。50 年同大学工学部勤務。 63 年〜平成元年カナダ・トロント大学電 気工学科 Postdoctoral Fellow。現在, 岩手大学工学部助教授。工学博士(東北大学)。磁気立体回 路素子, 磁性流体応用デバイスおよび磁性流体の磁気計測 法に関する研究に従事。IEEE Senior Momber。

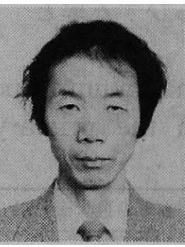

山田弘（正員）

昭和 54 年北海道大学大学院工学研究 科博士課程満了。同年岩手大学工学部勤 務。59 年 61 年 MIT 客員研究員。現 在, 岩手大学工学部助教授。工学博士 (北海道大学)。誘電体の高電界現象に関する研究に従事。 日本物理学会会員。

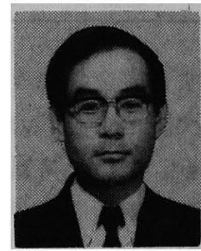

藤 原 民 也（正員）

昭和 48 年東北大学大学院工学研究科 修士課程修了。50 年岩手大学工学部勤 務。62 年 63 年 MIT 客員研究員。現 在, 岩手大学工学部助教授。工学博士 (東北大学)。電気光学効果を用いた電界計測および放電に 関する研究に従事。応用物理学会会員。 